\title{
HYDROLOGICAL DROUGHT EXPERIENCED IN THE TREBES - NEGEL REPRESENTATIVE RIVER BASIN DURING 2013-2017
}

DOI: http://dx.doi.org/10.18509/GBP.2019.25

UDC: 556.1.06:551.577.38(498)

\author{
Larisa Paveluc ${ }^{1,2}$ \\ Gianina Cojoc ${ }^{2}$ \\ Grozavu Adrian ${ }^{1}$ \\ Elena Hutanu ${ }^{1}$ \\ Dan Lucian Ciurte ${ }^{1}$ \\ ${ }^{1}$ Alexandru Ioan Cuza University of Iasi, Faculty of Geography and Geology, Department of \\ Geography, Bd. Carol I 20A, 700505, Iasi, Romania \\ ${ }^{2}$ Siret Water Basin Administration, Bacau, 1 Cuza Voda Str., 600274, Bacau, Romania
}

\begin{abstract}
One of the climatic hazards experienced in recent times is the drought that affects the society and the ecosystems. This study is intended to identify the statistically significant trends in the minimum flow characteristics and hydrological drought episodes, during five years, of the Trebes-Negel representative river basin, located in the Moldavian Sub Carpathians, in Romania. It is an important hydrological objective used for research purposes, considered as a reference point for all small basins with an identical natural environment. Data analysis revealed that drought is recorded at two of the 6 hydrometric stations analyzed (Podis and Magura) in 2015, starting in August and ending with October.
\end{abstract}

Keywords: hydrological drought, minimum flow, Trebes-Negel River Basin, Moldavian Subcarpathians

\section{INTRODUCTION}

Water, as a basic component of the environment and the development of the economy, is a subject of major importance to whom numerous researches both at international [1-3] and national [4-8] level are devoted. In the context of economic development, water resources are used in households, as drinking or domestic water, in agriculture, animal husbandry, and industry. Each of these sectors requires a certain need for water, which today depends largely on the level of development of infrastructure and logistics, elements closely related to the degree of urbanization and alignment to specific standards. A frequently analyzed aspect is the quality of surface water [9-12], including the peak or minimum flow periods.

The demand for water remains constant or increasing, regardless of periods of drought. As a complex climatic phenomenon, drought is determined both by the climatic peculiarities of a region and those of the active surface. Drought is one of the imbalances that can occur at ground level and can be classified into three categories: meteorological, hydrological and pedological [13]. Generally, drought can be evaluated using indices that can be grouped into rainwater indices, hydric balance indices, and indices based on the spectral response of the underlying surface. Studies conducted in Romania characterize drought by using rainfall indices (e.g. Hellman criterion), aridity indices, soil water balance, climograms, etc. 
Hydrologic drought is a period of time characterized by the lack of precipitation and the presence of extreme temperatures [14]. During these periods there is a decrease of the watercourses and lakes levels, in some cases with lower values of the underground water and a possible drying of the soil. This type of drought is favored by other factors, such as morphometric, geological and hydrogeological conditions, and anthropogenic activities [14].

The current study is intended to identify the statistically significant trends in the minimum flow characteristics and hydrological drought episodes of the Trebes-Negel River Basin, considered as a reference point for all small basins in Romanian Subcarpathians, affected by severe drought in recent years.

\section{STUDY AREA}

The Trebes-Negel River Basin is located in the Moldavian Subcarpathians, which constitute a complex structural unit bordering the Eastern Carpathians in Romania. It is a small basin created by the river Trebes and its tributaries, developed within the lower sector of the important basin of Bistrita River, with NW-SE orientation and an area of about $140 \mathrm{~km}^{2}$. Mathematically, the basin is bounded by the parallels of $46^{\circ} 30^{\prime}$ and $46^{\circ}$ $40^{\prime}$ North latitude and by the meridians of $26^{\circ} 40^{\prime}$ and $26^{\circ} 52^{\prime}$ East longitude (Fig. 1). In the case of Trebes tributaries, the rivers Slatina, Carligati and Negelul (which are tributaries on the right side) have a cadastral code as they have a length of at least $5 \mathrm{~km}$ and the surface of the receiving basin of at least $10 \mathrm{~km}^{2}$.

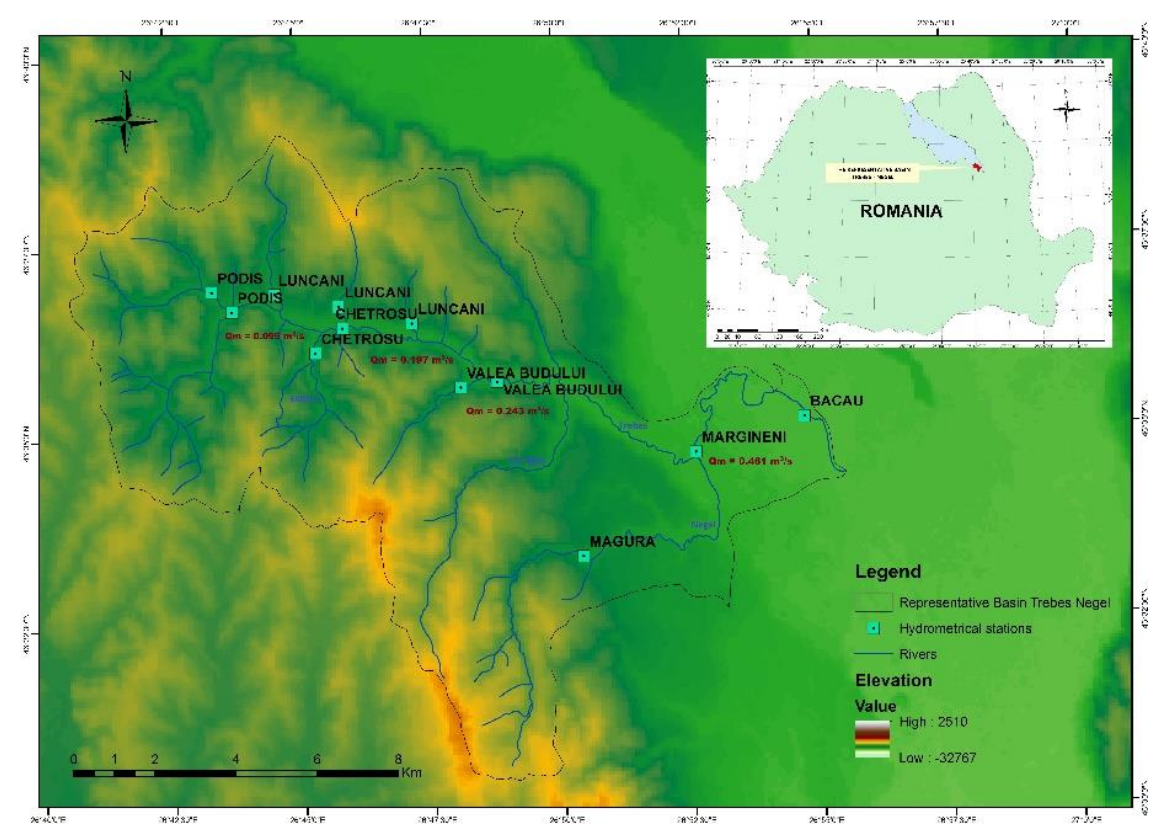

Figure 1. The geographical localization of the Trebes-Negel Representative River Basin and its hydrometric stations accompanied by multiannual flow $(\mathrm{Qm})$

The geographic features are those specific to the Eastern Subcarpathian region, developed on Paleogene and Neogene geological deposits, with frequent deep and shallow alternance of various lithology such as clays, marl-clays, sandstones, sands, gravel, loams, etc. The mean annual precipitations vary around 530-670 $\mathrm{mm}$, heavy rainfalls being characteristic [15]. The rivers have a discontinuous hydrological regime, with frequent periods of lack of flow. Within the natural vegetation, the forested areas occupy important percentages, even though in the last century the forest surface decreased 
especially around villages, being replaced by secondary meadows, orchards, or by the extension of settlements.

\section{METHODOLOGY}

We have used the hydrological database obtained from the Administration of the Siret Basin (Bacău) for a period of 5 years (2013-2017). The observation and measurement program conducted in the Trebes-Negel Representative Basin includes: level observations, stream gauging, and rainfall measurement. These data are useful both for practical purposes and for fundamental research.

The hydrometric stations along the Trebes River are the Podis hydrometric station, Chetrosu hydrometric station, Valea Budului hydrometric station, and Margineni hydrometric station. There is only one hydrometric station on the Negel River - the Magura Hydrometer Station. Also, for our study, we used the data from the Bacau hydrometric station, which is not included in the Trebes-Negel Representative Basin (being located at the confluence of Trebes with its tributary on the left, Limpedea).

Materials, observations, and measurements required were field procurement at least twice a day (standard daily measurement hours are 06:00 and 18:00) at the 6 hydrometric stations analyzed. The programs used to represent the results were: ArcGIS, for cartographic representation and Microsoft Office Excel, for graphic representation.

\section{RESULTS AND DISCUSSIONS}

For the analysis of the regional hydrological drought, the minimum flow rate was determined at the six hydrological stations. After a comparative analysis of the multiannual average values of the flow and precipitation (Fig. 2), we observed that in the years 2013 and 2015 the values are lower compared to the other years.

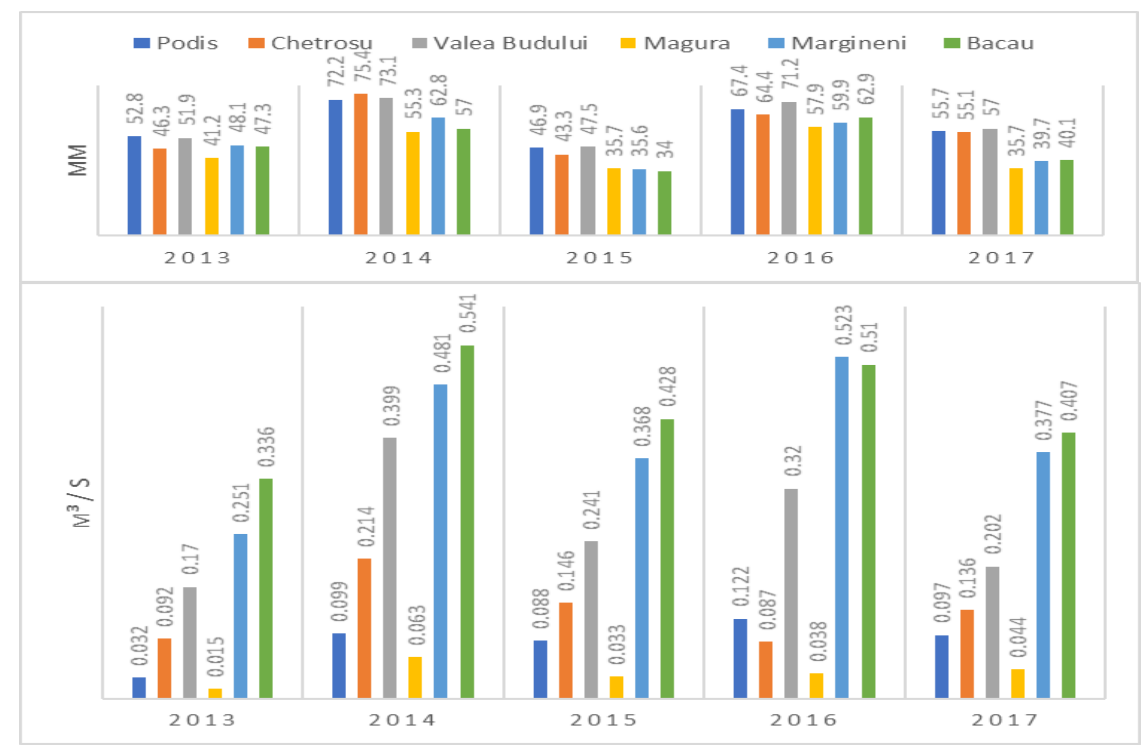

Figure 2. The multiannual rainfall and flow from 2013 to 2017 registered at the Podis, Chetrosu, Valea Budului, Magura, Margineni and Bacau hydrometric stations

In 2013 (Fig. 3), the minimum flows were recorded in August and September when rainfall at the Podis hydrometric station in August was $59.5 \mathrm{~mm}$, and in September it was $61.1 \mathrm{~mm}$. The August average temperatures are around $21-22{ }^{\circ} \mathrm{C}$ in August and 
$12.7^{\circ} \mathrm{C}$ (at Valea Budului's hydrometric station) - 15.3 (at the Magura hydrometric station) in September [1].
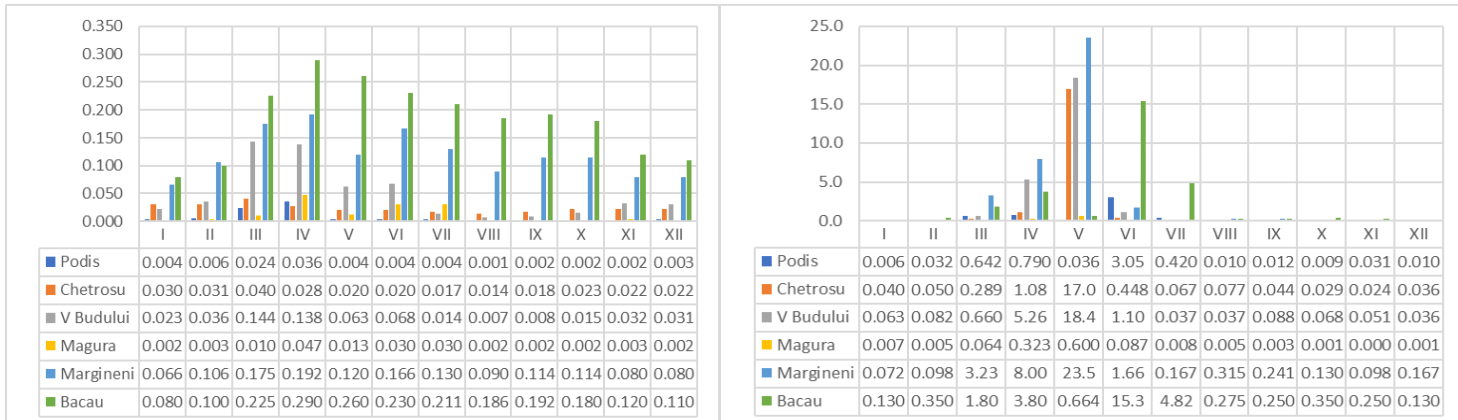

Figure 3. Minimum and maximum monthly flows of 2013 registered at the Podis, Chetrosu, Valea Budului, Magura, Margineni and Bacau hydrometric stations
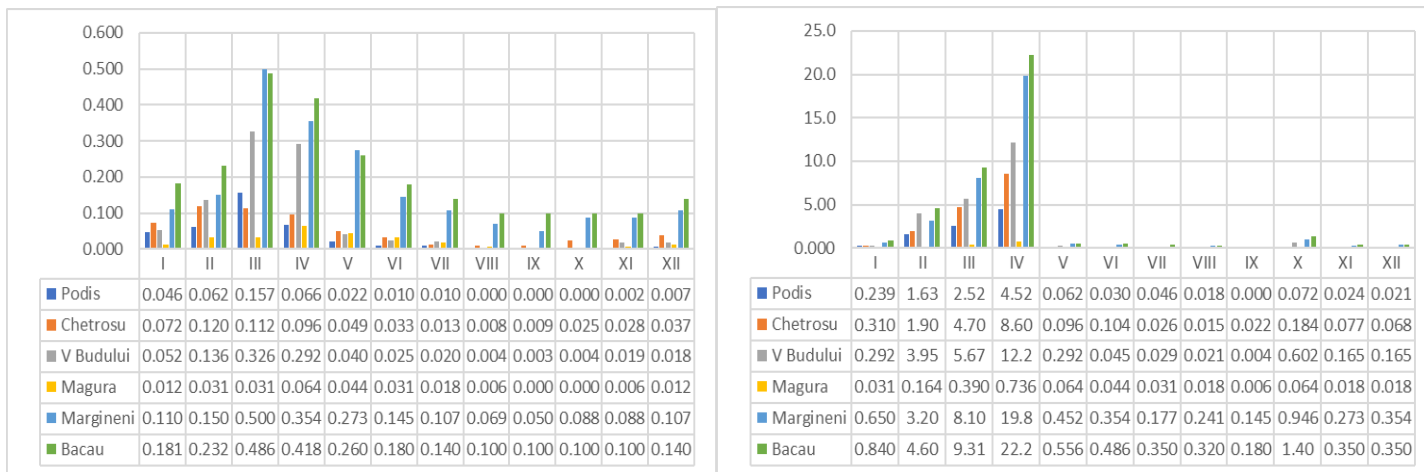

Figure 4. Minimum and maximum monthly flows of registered at the Podis, Chetrosu, Valea Budului, Magura, Margineni and Bacau hydrometric stations

In the five years analyzed, in 2015 (Figure 4) at the Podis hydrometric station occurs the phenomenon of waterlogged (the water level is recorded but there is no water velocity, respectively flow) for a total duration of 56 days (between August 10 and October 5). At the Magura hydrometric station, on the Negel River, the 36 days of depletion (September 6 - October 11).

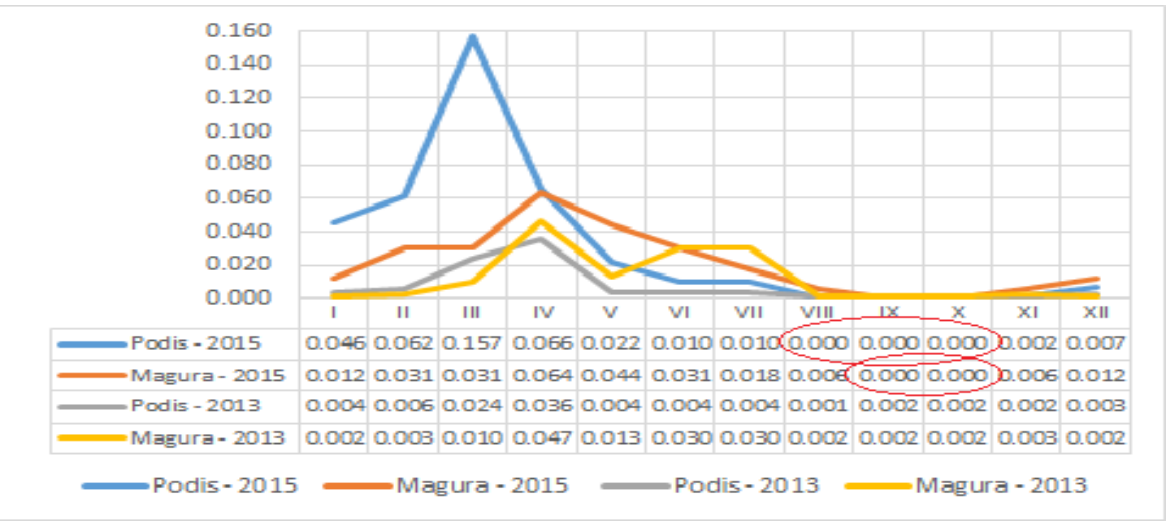

Figure 5. Minimum monthly flows of 2013 and 2015 registered at the Podis and Magura hydrometric stations

In the months when the waterlogged phenomenon was recorded (Podis hydrometric station), precipitation was recorded: in August $21.6 \mathrm{~mm}$, in September $34.1 \mathrm{~mm}$ and in 
October $100.0 \mathrm{~mm}$. And at the Magura hydrometric station, on the Negel river there was a lower amount of precipitation, as follows: in September $50.2 \mathrm{~mm}$ and in October 79.6 $\mathrm{mm}$.

The stations where the drought phenomenon has been recorded for a long period of time are the Podis and Magura hydrometric stations. The average monthly flows at which two stations in 2015 show that for 3 months the flow of zero 1/ s was recorded at the Podis hydrometric station and also at the Magura hydrometer station, the difference being that there were recorded only two months. In 2013 we can see that the flows are quite low, we can see flows ranging between $0.001 \mathrm{~m}^{3} / \mathrm{s}$ and $0.003 \mathrm{~m}^{3} / \mathrm{s}$.

The obtained data in our study fall within the specific pattern for the Eastern SubCarpathian area of Romania. Here the minimum flows are recorded after long periods in which the supply from superficial sources is missing, the main role in the supply of rivers being taken over by the groundwater sources. Generally, the smallest flows are recorded during the winter, when rainfall is stored on the surface of the soil in the form of snow. A second low-flow period is summer-autumn as a result of very low rainfall from August to September and still high temperatures that keep important evaporation in the catchment basins.

At the same time, minimal flows are greatly influenced by the heterogeneity of the lithological constitution. Thus, the permeable rocks that form the substrate favor infiltration processes and fail to contribute to the formation of rich underground waters capable to provide power supply in periods of deficient humidity. The rivers that drain the eastern slope of the Oriental Carpathians frequently bear the phenomenon of drying up in their lower sector, with the mention that the notion of "drying" has rather a physical significance, from the hydrological point of view being more correct the notion of "infiltration in the talweg" [16].

\section{CONCLUSIONS}

The goal of this study is to identify the statistically significant trends in the minimum flow characteristics and hydrological drought episodes of a small river basin in Romanian Subcarpathians, affected by drought in recent years. This region, through its geographic position, has some features specific to semiarid areas, with prolonged drought periods, a discontinuous hydrological regime with corresponding complex geographic effects.

Research on hydrological droughts highlights an increase in its frequency. Even though the present study only refers to a small-scale basin and covers a very short period of time, it is possible to observe the climatological and, implicitly, the hydrological changes.

We have used hydrological data recorded over a period of 5 years (2013-2017) at six hydrometric stations comprising: water level observations, liquid flow determinations, and rainfall measurement. Their processing revealed that the longest period of depletion was 36 days at the Magura hydrometric station and the waterlogged phenomenon at the Podis hydrometric station for 56 days.

\section{REFERENCES}

[1] Chen Z.M., Yeh Y.L. \& Chen T.C. Assessment of a Regional Flood Disaster Indicator via an Entropy Weighting Method. Natural Hazards Review, 2018.

[2] Yang H.C., Wang C.Y. \& Yang J.X. Applying image recording and identification for measuring water stages to present flood hazards, Natural Hazards, pp 737-754, 2014. 
[3] Zeleňáková M., Soláková T., Purcz P., Simonová D. \& Kuzevičová T. Drought Regionalization Based on Low Flow Trends in Selected River Basins in Slovakia, International Journal of Environmental Science and Development, pp 581-585.

[4] Cojoc G., Romanescu G. \& Tirnovan A. Exceptional floods on a developed river. Case study for the Bistrita River from the Eastern Carpathians (Romania). Natural Hazards, Romania, pp 1421-1451, 2015.

[5] Reti K.O., Malos C.V. \& Manciula I.D. Hydrological risk study in the Damuc village, the Neamt county. Journal of Environmental Protection and Ecology, Romania, pp 142-148, 2014.

[6] Romanescu G. \& Stoleriu C. Causes and Effects of the Catastrophic Flooding on the Siret River (Romania) in July-August 2008, Natural Hazards, Romania, pp 1351-1367, 2013.

[7] Romanescu G., Cimpianu C.I., Mihu-Pintilie A. \& Stoleriu C.C. Historic flood events in NE Romania (post-1990), Journal of Maps, Romania, pp 787-798, 2017.

[8] Romanescu G., Mihu-Pintilie A., Stoleriu C.C., Carboni D., Paveluc L.E. \& Cimpianu C.I. A Comparative Analysis of Exceptional Flood Events in the Context of Heavy Rains in the Summer of 2010: Siret Basin (NE Romania) Case Study. Water, Romania, pp 1-17, 2018.

[9] Romanescu G., Tarnovan A., Sandu I.G., Cojoc G.M., Dascalita D. \& Sandu I. The Quality of Surface Waters in the Suha Hydrographic Basin (Oriental Carpathian Mountains). Rev. Chim. (Bucharest), Romania, pp 1168-1171, 2014.

[10] Romanescu G., Cojoc G.M., Sandu I.G., Tirnovan A., Dascalita D. \& Sandu I. Pollution Sources and Water Quality in the Bistrita Catchment (Eastern Carpathians). Rev. Chim. (Bucharest), Romania, pp 855-863, 2015.

[11] Sánchez-Rodríguez A.R., Chadwick D.R., Tatton G.S., Hill P.W. \& Jones D.L. Comparative effects of prolonged freshwater and saline flooding on nitrogen cycling in an agricultural soil, Applied Soil Ecology, 2018.

[12] Tokar A., Negoitescu A., Hamat C. \& Rosu S. The Chemical and Ecological State Evaluation of a Storage Lake. Rev.Chim.(Bucharest), Romania, pp 1860-1863, 2016.

[13] Quiring S.M. \& Ganesh S. Evaluating the utility of the Vegetation Condition Index (VCI) for monitoring meteorological drought in Texas, Agricultural and Forest Meteorology 150, 330 339, 2010.

[14] Zeleňáková M., Sol'áková T., Purcz P. \& Simonová D. Hydrological Drought Occurrence in Slovakia, Springle, pp 69-90, 2018

[15] Apostol L. Precipitatiile atmosferice in Subcarpatii Moldovei, Editura Universitatii Suceava, Romania, 2000.

[16] Olariu P. \& Nour M. Aspecte ale unor viituri excepţionale produse în ultimii ani în aria pericarpatică orientală, Lucr. Sem. Geogr. "Dimitrie Cantemir”, nr. 13-14, 1993-1994, Iaşi. 